\title{
Assessment of Physico-chemical Characteristics of Mangrove Region in the Krishnapatnam Coast, India
}

\author{
P. Sri Dattatreya ${ }^{1 *}$, K. Madhavi ${ }^{1}$, B. Satyanarayana ${ }^{2}$, Adnan Amin ${ }^{1}$ and C. Harini ${ }^{3}$ \\ ${ }^{1}$ Department of Aquatic Environment Management, College of Fishery Science, Muthukur, \\ Andhra Pradesh, India \\ ${ }^{2}$ Department of Fisheries and Economics and Statistics, Faculty of Fishery science, West \\ Bengal University of Animal and Fishery science, Kolkata, India \\ ${ }^{3}$ Department of Aquaculture, Fisheries College and Research Institute, Thoothukudi, India
}

*Corresponding author

\begin{tabular}{|c|c|}
\hline & $\mathbf{T}$ \\
\hline $\begin{array}{l}\text { Ke y w o r d s } \\
\text { Physico chemical, } \\
\text { Mangroves, } \\
\text { Krishnapatnam } \\
\text { coast, Pearson } \\
\text { correlation }\end{array}$ & \multirow{3}{*}{$\begin{array}{l}\text { The present investigation was carried out to assess the physico-chemical characteristics of } \\
\text { Mangrove region in the Krishnapatnam coastal region (Southeast coast of India) for a } \\
\text { period of ten (10) months from June } 2016 \text { to March } 2017 \text {. Surface water samples were } \\
\text { collected from the chosen sampling stations at fortnightly intervals and analyzed to } \\
\text { provide baseline information on the physico-chemical characteristics of these coastal } \\
\text { biotopes. During the study period, variations observed in different water quality } \\
\text { parameters of mangrove stations respectively are as follows: Rainfall }(392.60 \mathrm{~mm} \text { ), Air } \\
\text { temperature in }{ }^{\circ} \mathrm{C}\left(25.4 \text { to } 31.2^{\circ} \mathrm{C}\right) \text {, Water temperature in }{ }^{\circ} \mathrm{C}\left(25^{\circ} \mathrm{C} \text { to } 28.8^{\circ} \mathrm{C}\right) \text {, pH (7.4- } \\
8.1) \text {, salinity in ppt }(21-33), \mathrm{EC} \text { in } \mathrm{mS} / \mathrm{cm}(32.81-51.56) \text {, DO in } \mathrm{mg} / \mathrm{L}(2.7-5.0) \text {, BOD in } \\
\mathrm{mg} / \mathrm{L}(1.14-3.68) \text {, total alkalinity in } \mathrm{mg} / \mathrm{L}(112-168) \text {, total hardness in mg/L }(3349-5463) \text {, } \\
\text { total solids in } \mathrm{g} / \mathrm{L}(24.5-33.7) \text {, TSS in } \mathrm{g} / \mathrm{L}(0.7-3) \text {, total ammonia in } \mu \mathrm{g} / \mathrm{L}(3.6-19.8) \text {, nitrite } \\
\text { in } \mu \mathrm{g} / \mathrm{L}(0.36-3.52) \text {, nitrate in } \mu \mathrm{g} / \mathrm{L}(1.84-4.85) \text {, phosphate in } \mu \mathrm{g} / \mathrm{L}(1.021-3.65) \text {. }\end{array}$} \\
\hline Article Info & \\
\hline $\begin{array}{l}\text { Accepted: } \\
\text { 18 April } 2018 \\
\text { Available Online: } \\
10 \text { May } 2018\end{array}$ & \\
\hline
\end{tabular}

\section{Introduction}

The Indian mangroves cover about $4827 \mathrm{Km} 2$, with about $57 \%$ of them along the east coast, $23 \%$ along the west coast, and 20\% in Andaman and Nicobar Islands (Venkataraman and Wafar, 2005). The mangrove ecosystem holds and stabilizes the environment from erosion and acts as a buffer zone between land and sea. In India, mangrove forests cover $3,60,000$ ha of coastal tracts $(3 \%$ of the world's mangrove forest) (Badarudeen et al.,
1996; Mastallar, 1996). Mangrove forests have the highest productivity among coastal wetlands after coral reefs. Around $90 \%$ of all marine organisms spend some portion of their life cycle within the mangrove ecosystem (Adeel and Pomeroy, 2002). Mangrove ecosystem commands the highest importance because of its biological productivity and specialized diversity. The study of water quality parameters of mangrove region is necessary as they are highly productive and play an important role as breeding and nursery 
grounds for many commercially important fishes (both 'fin and shell fishes') especially shrimps (Kathiresan and Bingham, 2001). Recently, reclamation of mangrove ecosystems for industrial, urban and other forms of development has been increasing and it causes irreversible damage in coastal regions throughout the tropics. Coastal mangroves have the potential to improve the water quality of urban and rural runoff before it is discharged into adjacent coastal bays and oceans, but they also can be impaired by excessive pollutants from upstream. Though their importance to humans, wildlife, and global carbon balance is paramount, globally mangroves are generally undervalued, overexploited and poorly managed. Wahid et al., (2007) carried out hydrologic monitoring by analyzing the different physico-chemical parameters of Sundarban mangrove ecosystem, Bangladesh. They reported that the waterways were not organically polluted and the quality of water with respect to different parameters is within the Environmental Quality Standards (EQS) of Bangladesh, with the average dissolved oxygen content of 5.99 $\mathrm{mg} / \mathrm{L}$.

Mangrove wetlands are one of the world's most threatened ecosystems and mangroves (coastal woodlands or oceanic rain forests) are important wetlands along tropical and subtropical coasts, particularly along deltas and bays where rivers discharge freshwater and sediment to the sea, that provide ecological security, environmental sustainability, and economic prosperity.

\section{Materials and Methods}

\section{Study area}

Krishnapatnam coastal area is having dense mangroves, the study site lies between the Latitude $14.2546^{\circ} \mathrm{N}$ and Longitude $80.1094^{\circ} \mathrm{E}$. The mangroves exit along the Kandaleru creek, over a length of about $10 \mathrm{Km}$ behind Krishnapatnam, where it merges with the Bay of Bengal. The study area is divided into two stations; Station 1 is near to port area, Penna cement industry' is there near to this station. Station 2 is near to aquaculture ponds this site is having the chance to release the effluents into mangroves environment (Fig. 1).

\section{Sampling strategy, sample collection, and processing}

Surface water samples were collected once in fifteen days from all the selected stations for a period of 10 months from June 2016 to March 2017 in the early hours of the day, for the estimation of selected physico-chemical parameters. The study period (June to March) was divided into two different seasons, viz., south-west monsoon (June to August), monsoon transition period (September and October), north-east monsoon (November and December), post-monsoon/winter (January and February) and summer (March) based on the regional cyclic phenomena of meteorological events. The quantum of rainfall received in the region during the study period was obtained from Agricultural Research Station (ARS), S.P.S.R. Nellore Dist.

Water samples were tested for different physico-chemical parameters. A water characteristic of dissolved oxygen (DO) and Biological Oxygen Demand (BOD) was estimated Winkler-azide method. Air and Water temperature were recorded by using a 'standard mercury centigrade thermometer and salinity by the Mohr-Knudsen titration method. Electrical conductivity was measured using 'digital conductivity meter' (Systronics, 306). Total alkalinity and Total hardness were analyzed in the laboratory by following standard method described in APHA (2005). Gravimetric analysis of Total Solids (TS) and Total suspended solids were determined by 
using Millipore filtration assemblage by employing the method described in APHA (2005). The water nutrients like Ammonia, Nitrites, Nitrates, and Phosphates were analyzed by UV-Visible Spectrophotometer (T 60 LABINDIA) of standard methods (Strickland and Parsons, 1972).

\section{Statistical analysis}

Statistical analysis was carried out using software package 'SPSS 22". Pearson correlation coefficient was calculated to test the degree of relationship between the selected parameters under study. Dendrogram is a hierarchical clustering technique, which was used to know the interrelationship of fortnight samples.

\section{Meteorological parameters}

\section{Rainfall}

Rainfall is the most important cyclic phenomenon in tropical countries, as it brings important changes in the hydrological characteristics of the coastal ecosystems. During the study period, the area experienced a total of $392.60 \mathrm{~mm}$ rainfall. Rainfall ranged between $4.00 \mathrm{~mm}$ to $160.20 \mathrm{~mm}$ and February, March months remained practically rainless. The peak value of rainfall was recorded during monsoon (N-E) month of December (160.2 $\mathrm{mm}$ ) minimum precipitation was observed in the month of January $(4 \mathrm{~mm})$. Of the total precipitation received during the study period, nearly $48 \%$ was during N-E monsoon season, this is in accordance with Subramanian (1999) who reported that south-east coast of India receives bulk rainfall during $\mathrm{N}-\mathrm{E}$ monsoon (Fig. 2).

\section{Air temperature}

The air temperature varied from $25.4^{\circ} \mathrm{C}$ to $31.2^{\circ} \mathrm{C}$, the air temperature showed marked variation in relation to seasons. The observed high values of air temperature during summer it can be attributed to the intense solar radiation and lower values during monsoon seasons confirmed the general established trends along the south-east coast. Kumara and Kumar (2011) found the air temperature between $24^{\circ} \mathrm{C}$ to $29^{\circ} \mathrm{C}$ while working on Kundapur mangroves. Ramamurthy et al., (2012) observed air temperature in the range of $27^{\circ} \mathrm{C}$ to $29^{\circ} \mathrm{C}$ in Vedaranyam mangrove forest. Srilatha et al., (2013) noticed air temperature in the range of $25^{\circ} \mathrm{C}$ to $35^{\circ} \mathrm{C}$ in Muthupettai mangroves (Fig. 3).

\section{Hydrographical parameters}

\section{Water temperature}

Water temperature is of enormous significance as it regulates the biological activities and governs the solubility of gases in water. The water temperature ranged between $25^{\circ} \mathrm{C}$ to $28.8^{\circ} \mathrm{C}$. Generally, surface water temperature is influenced by the intensity of solar radiation, evaporation, freshwater influx and cooling and mix up with the ebb and flow from adjoining neritic waters. In the present study, summer peaks and monsoonal/postmonsoonal troughs were observed and surface water temperature showed a similar trend to that of air temperature. Observed low water temperature during monsoon (N-E) might be due to shorter photoperiod, decreased atmospheric temperature. Kumara and Kumar (2011) observed water temperature ranging from $23^{\circ} \mathrm{C}$ to $27^{\circ} \mathrm{C}$ along the mangrove area of Kundapur. Ramamurthy et al., (2012) observed water temperature in the range of 26 to $280 \mathrm{C}$ at the Vedaranyam mangrove forest. Behera et al., (2008) noticed water temperature ranging between $24.2^{\circ} \mathrm{C}$ and $30.9^{\circ} \mathrm{C}$ along the Mangrove ecosystem of Mahanadi river delta. Jitthaisong et al., (2012) observed water temperature in the range of $26.69^{\circ} \mathrm{C}$ to $27.68^{\circ} \mathrm{C}$ along the mangrove forest and coastal area of Phetchaburi Province, Thailand (Fig. 4). 
Table.1 Correlation matrix for water quality parameters of M1

\begin{tabular}{|c|c|c|c|c|c|c|c|c|c|c|c|c|c|c|c|}
\hline & AT & WT & pH & EC & SALINITY & DO & BOD & TA & TH & TS & TSS & $\mathbf{N H}_{3}$ & $\mathrm{NO}_{2}$ & $\mathrm{NO}_{3}^{-}$ & $\mathrm{PO}_{4}{ }^{-}$ \\
\hline AT & 1.000 & & & & & & & & & & & & & & \\
\hline WT & $.825^{* *}$ & 1.000 & & & & & & & & & & & & & \\
\hline pH & 0.353 & 0.090 & 1.000 & & & & & & & & & & & & \\
\hline EC & $.448^{*}$ & 0.443 & 0.273 & 1.000 & & & & & & & & & & & \\
\hline SALINITY & $.655^{* *}$ & $.454^{*}$ & 0.361 & 0.332 & 1.000 & & & & & & & & & & \\
\hline DO & $-.516^{*}$ & $-.484^{*}$ & -0.201 & $-.470^{*}$ & $-.604^{* *}$ & 1.000 & & & & & & & & & \\
\hline BOD & -0.272 & -0.324 & 0.051 & -0.438 & -0.363 & $.662^{* *}$ & 1.000 & & & & & & & & \\
\hline TA & 0.385 & 0.330 & $.740^{* *}$ & 0.378 & $.504^{*}$ & -0.367 & -0.065 & 1.000 & & & & & & & \\
\hline TH & 0.406 & 0.422 & $.455^{*}$ & -0.019 & 0.245 & -0.194 & -0.124 & $.471^{*}$ & 1.000 & & & & & & \\
\hline TS & 0.283 & 0.251 & $.456^{*}$ & 0.138 & $.588^{* *}$ & -0.157 & -0.214 & $.698^{* *}$ & $.654^{* *}$ & 1.000 & & & & & \\
\hline TSS & -0.224 & -0.114 & -0.174 & 0.130 & -0.415 & 0.165 & -0.129 & -0.189 & -0.042 & -0.139 & 1.000 & & & & \\
\hline $\mathbf{N H}_{3}$ & -0.287 & -0.218 & -0.104 & -0.043 & -0.348 & 0.145 & -0.050 & 0.038 & -0.057 & -0.057 & 0.212 & 1.000 & & & \\
\hline $\mathrm{NO}_{2}^{-}$ & -0.172 & -0.044 & -0.092 & 0.063 & -0.419 & 0.028 & 0.152 & -0.114 & 0.098 & -0.143 & 0.323 & -0.288 & 1.000 & & \\
\hline $\mathrm{NO}_{3}^{-}$ & $-.631^{* *}$ & -0.351 & -0.273 & -0.100 & $-.680^{* *}$ & 0.156 & 0.219 & -0.140 & -0.248 & -0.360 & 0.353 & $.494^{*}$ & $.477^{*}$ & 1.000 & \\
\hline $\mathrm{PO}_{4}^{-}$ & -0.382 & -0.257 & $-.650^{* * *}$ & -0.330 & $-.537^{*}$ & 0.438 & 0.178 & $-.805^{* *}$ & -0.431 & $-.548^{*}$ & 0.208 & -0.135 & 0.269 & 0.304 & 1.000 \\
\hline \multicolumn{16}{|c|}{ **. Correlation is significant at the 0.01 level (2-tailed). } \\
\hline \multicolumn{16}{|c|}{ *. Correlation is significant at the 0.05 level (2-tailed). } \\
\hline \multicolumn{16}{|c|}{ Listwise $\mathbf{N}=\mathbf{2 0}$} \\
\hline \multicolumn{16}{|c|}{$\mathrm{NH}_{3}-$ Ammonia, $\mathrm{NO}_{2}^{-}$Nitrite $\mathrm{NO}_{3}{ }^{-}$Nitrate, $\mathrm{PO}_{4}{ }^{-}$Phosphate } \\
\hline
\end{tabular}


Table.2 Correlation matrix for water quality parameters of M2

\begin{tabular}{|c|c|c|c|c|c|c|c|c|c|c|c|c|c|c|c|}
\hline & $\mathbf{A T}$ & WT & pH & EC & SALINITY & DO & BOD & $\mathbf{T A}$ & TH & $\mathbf{T S}$ & TSS & $\mathbf{N H}_{3}$ & $\mathrm{NO}_{2}$ & $\mathrm{NO}_{3}^{-}$ & $\mathrm{PO}_{4}^{-}$ \\
\hline AT & 1.000 & & & & & & & & & & & & & & \\
\hline WT & $.938^{* * *}$ & 1.000 & & & & & & & & & & & & & \\
\hline pH & 0.186 & 0.180 & 1.000 & & & & & & & & & & & & \\
\hline $\mathbf{E C}$ & 0.082 & 0.024 & 0.354 & 1.000 & & & & & & & & & & & \\
\hline $\begin{array}{c}\text { SALINIT } \\
\mathbf{Y}\end{array}$ & 0.371 & $.467^{*}$ & $.471^{*}$ & 0.131 & 1.000 & & & & & & & & & & \\
\hline DO & $0 . \overline{365}$ & $-.466^{*}$ & $\begin{array}{c}- \\
0.273\end{array}$ & -0.158 & $-.518^{*}$ & 1.000 & & & & & & & & & \\
\hline BOD & $\begin{array}{c}- \\
0.303\end{array}$ & $\begin{array}{c}- \\
0.320\end{array}$ & $\begin{array}{c}- \\
0.115\end{array}$ & -0.309 & $-.468^{*}$ & $.515^{*}$ & 1.000 & & & & & & & & \\
\hline TA & 0.358 & 0.397 & $.618^{* *}$ & 0.174 & $.456^{*}$ & $-.456^{*}$ & $0 . \overline{192}$ & 1.000 & & & & & & & \\
\hline TH & 0.000 & $\stackrel{-}{0.001}$ & 0.360 & 0.346 & 0.187 & -0.403 & $\begin{array}{c}- \\
0.199\end{array}$ & $.464^{*}$ & 1.000 & & & & & & \\
\hline TS & 0.168 & 0.224 & $.600^{* *}$ & 0.220 & $.444^{*}$ & -0.402 & $\begin{array}{c}- \\
0.296\end{array}$ & $.807^{\text {** }}$ & $.663^{* *}$ & 1.000 & & & & & \\
\hline TSS & 0.342 & 0.353 & $\stackrel{-}{0.064}$ & -0.183 & 0.050 & 0.116 & 0.217 & 0.203 & 0.237 & 0.282 & 1.000 & & & & \\
\hline $\mathbf{N H}_{3}$ & $-.515^{*}$ & $.571^{* *}$ & 0.251 & 0.045 & -0.343 & 0.304 & 0.006 & $\begin{array}{c}- \\
0.139\end{array}$ & 0.236 & $\begin{array}{c}- \\
0.058\end{array}$ & 0.063 & 1.000 & & & \\
\hline $\mathrm{NO}_{2}^{-}$ & $\begin{array}{c}- \\
0.287\end{array}$ & $\begin{array}{c}- \\
0.242\end{array}$ & $\begin{array}{c}- \\
0.117\end{array}$ & 0.070 & -0.339 & -0.101 & $\begin{array}{c}- \\
0.224\end{array}$ & 0.249 & 0.147 & 0.265 & 0.013 & 0.266 & 1.000 & & \\
\hline $\mathrm{NO}_{3}^{-}$ & $.565^{* *}$ & $.589^{* *}$ & $.734^{* *}$ & -0.308 & -0.423 & 0.317 & 0.064 & $\begin{array}{c}- \\
0.443\end{array}$ & $\begin{array}{c}- \\
0.190\end{array}$ & $\begin{array}{c}- \\
0.330\end{array}$ & 0.140 & $.632^{* *}$ & 0.363 & 1.000 & \\
\hline $\mathrm{PO}_{4}^{-}$ & $\begin{array}{c}- \\
0.352\end{array}$ & $\begin{array}{c}- \\
0.350\end{array}$ & $\begin{array}{c}- \\
0.243\end{array}$ & 0.045 & -0.332 & 0.425 & 0.160 & $\begin{array}{c}- \\
0.201\end{array}$ & $\begin{array}{c}- \\
0.005\end{array}$ & $\begin{array}{c}- \\
0.349\end{array}$ & 0.075 & 0.298 & 0.020 & 0.103 & 1.000 \\
\hline \multicolumn{16}{|c|}{ **. Correlation is significant at the 0.01 level (2-tailed). } \\
\hline \multicolumn{16}{|c|}{ *. Correlation is significant at the 0.05 level (2-tailed). } \\
\hline \multicolumn{16}{|c|}{ List wise $\mathbf{N}=\mathbf{2 0}$} \\
\hline $\mathrm{NH}_{3}-\mathbf{A m m}$ & ia, $\mathbf{N}$ & No & & $\mathrm{D}$ & Dhranla & & & & & & & & & & \\
\hline
\end{tabular}




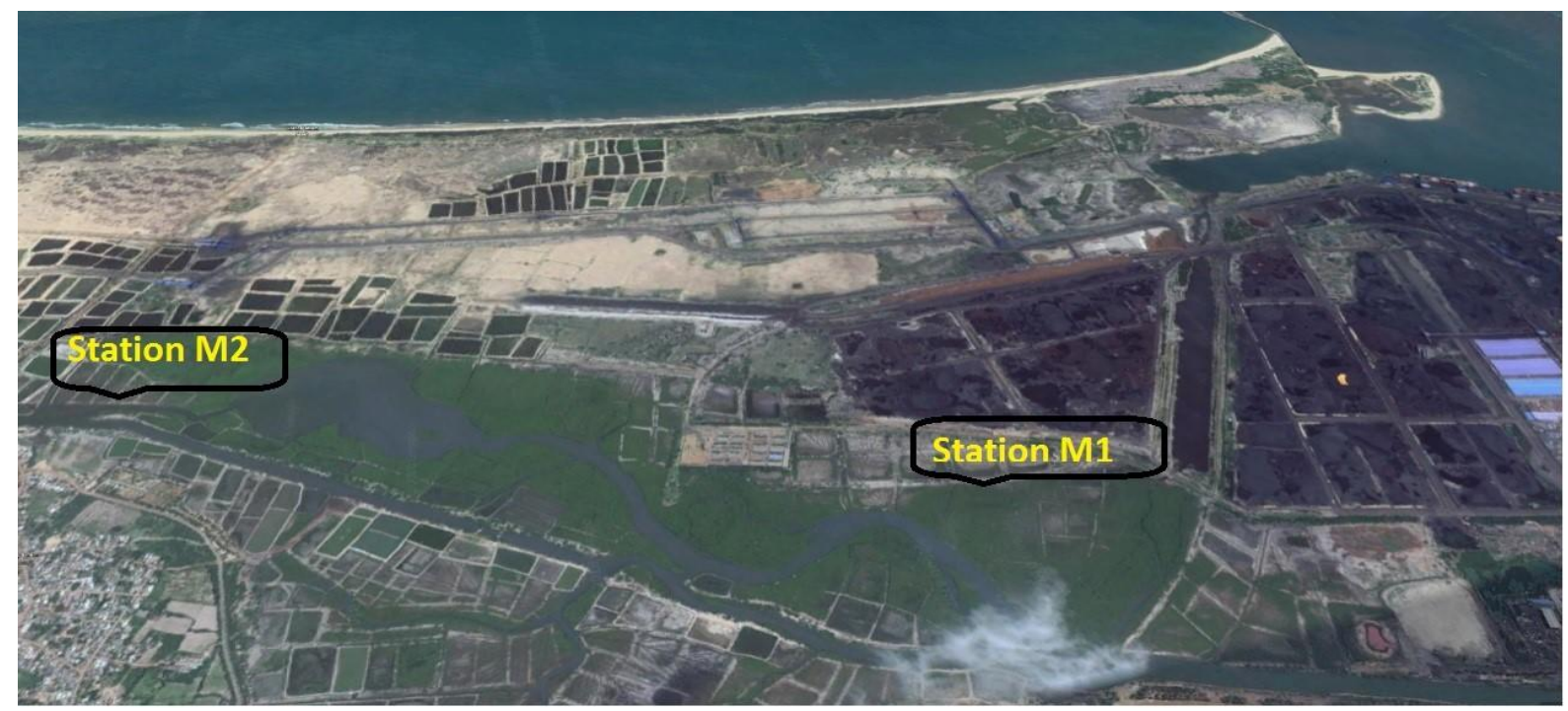

Fig.1 The map showing the study area and the sampling stations

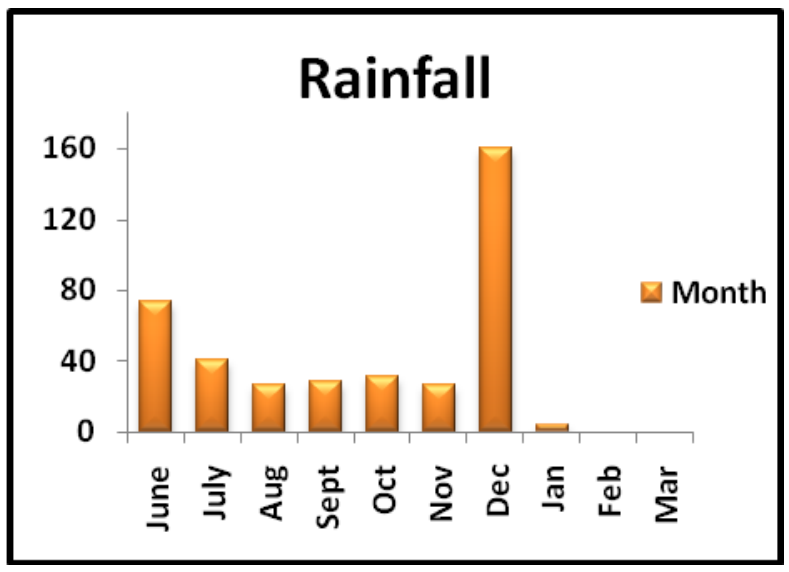

Fig.2 Monthly variations of Rainfall in Krishnapatnam coastal mangroves

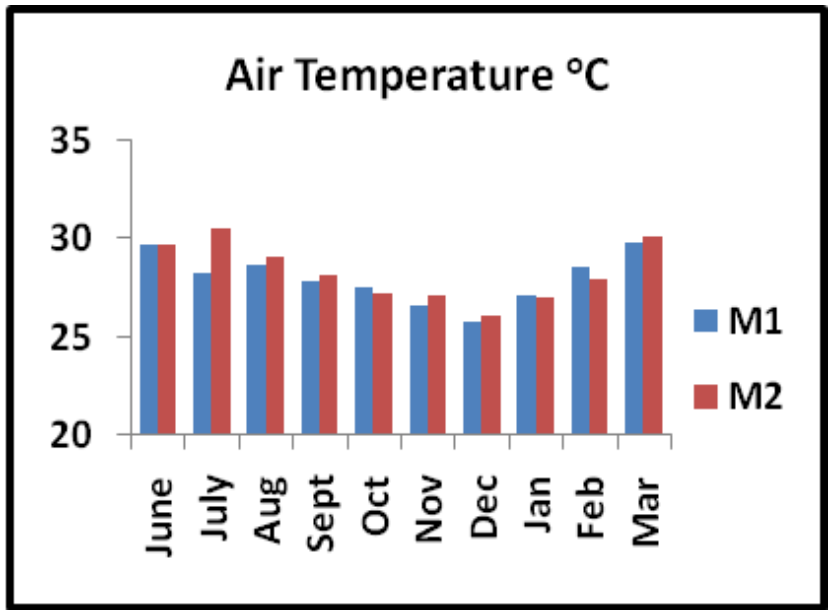

Fig.3 Monthly variation of Air-Temperature in Krishnapatnam coastal mangroves 


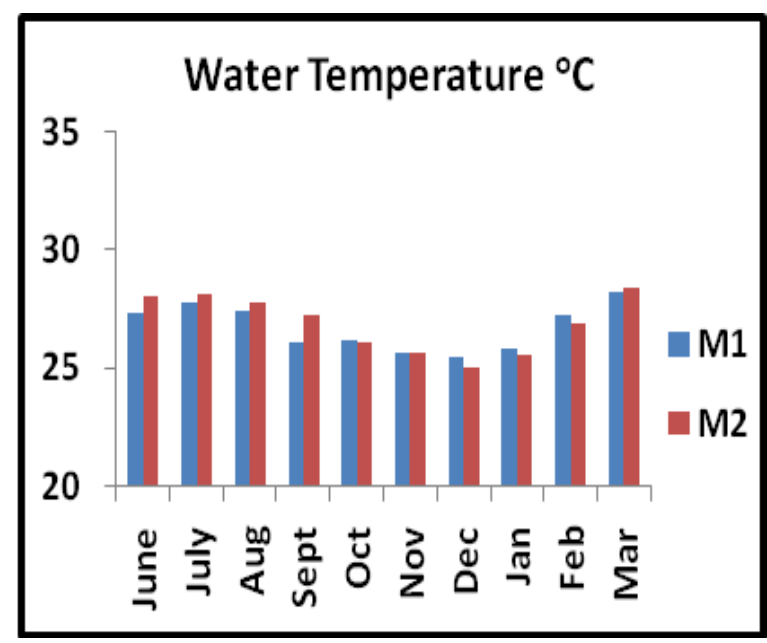

Fig.4 Monthly variation of Water Temperature in Krishnapatnam coastal mangroves

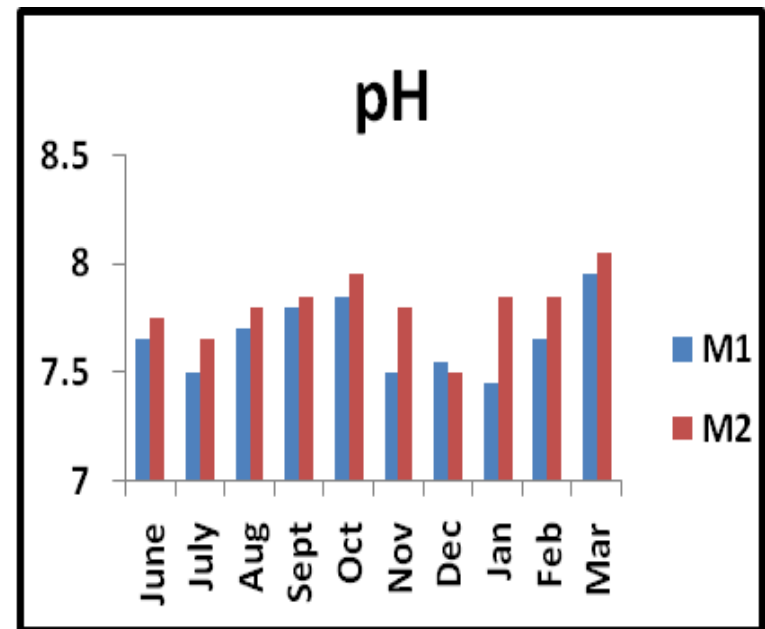

Fig.5 Monthly variation of $\mathrm{pH}$ in Krishnapatnam coastal mangroves

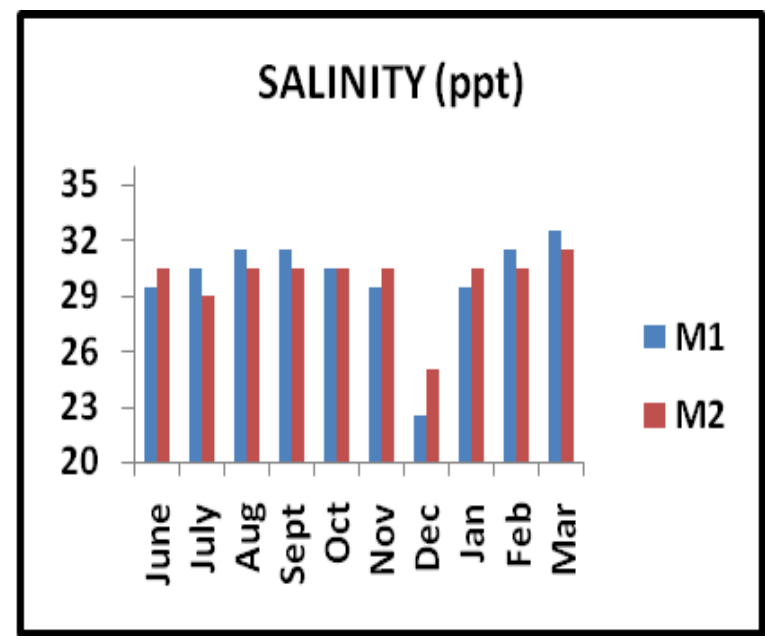

Fig.6 Monthly variation of salinity in Krishnapatnam coastal mangroves 


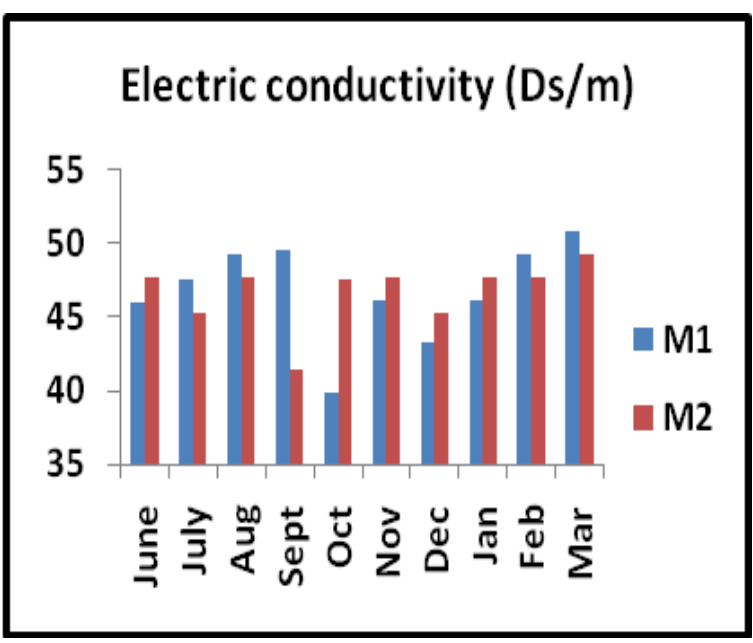

Fig.7 Monthly variation of electric conductivity in Krishnapatnam coastal mangroves

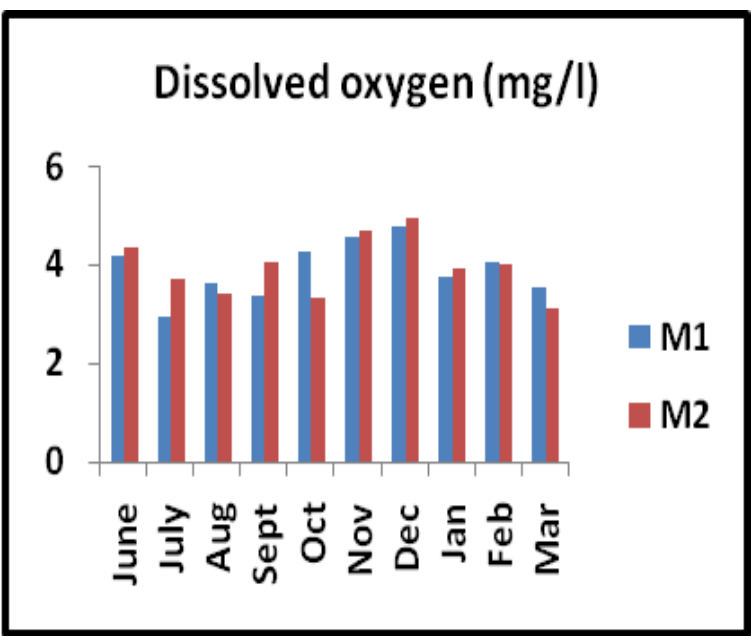

Fig.8 Monthly variation of dissolved oxygen in Krishnapatnam coastal mangroves

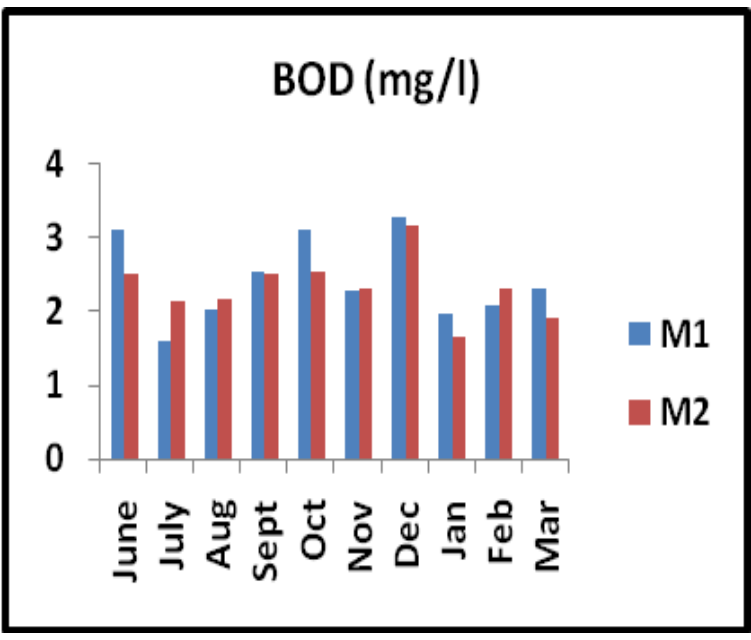

Fig.9 Monthly variation of biochemical oxygen demand in Krishnapatnam Coastal mangroves 


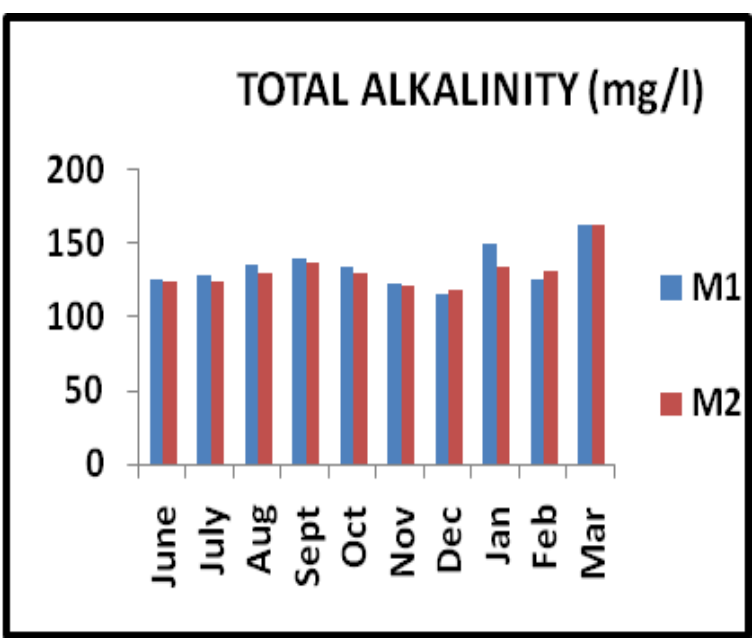

Fig.10 Monthly variation of total alkalinity in Krishnapatnam coastal mangroves

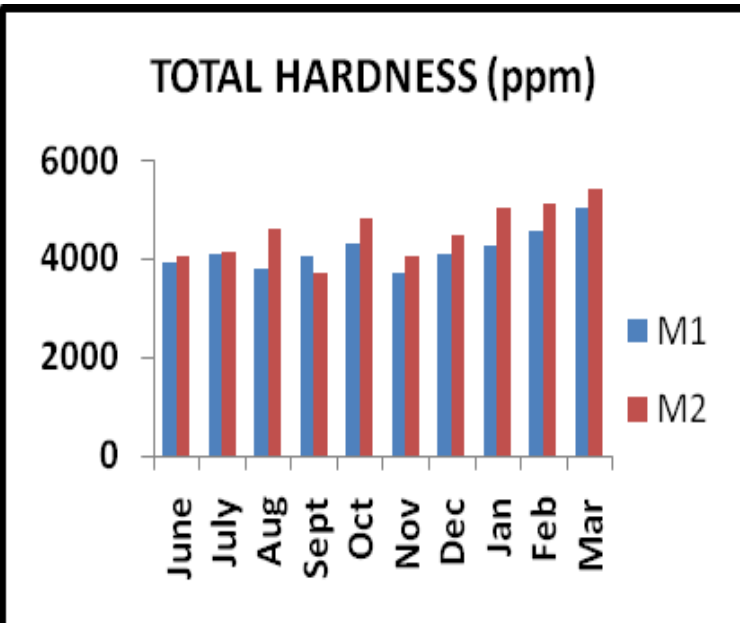

Fig.11 Monthly variation of total hardness in Krishnapatnam coastal mangroves

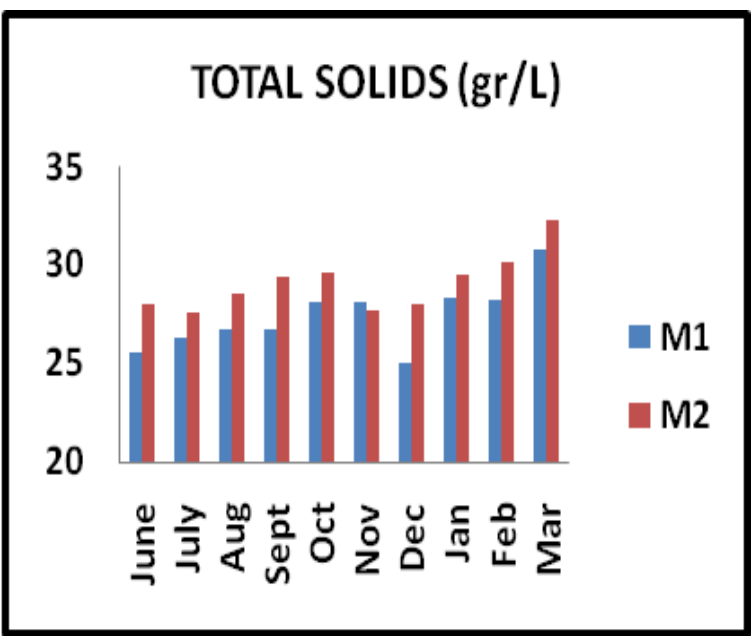

Fig.12 Monthly variation of total solids in Krishnapatnam coastal mangroves 


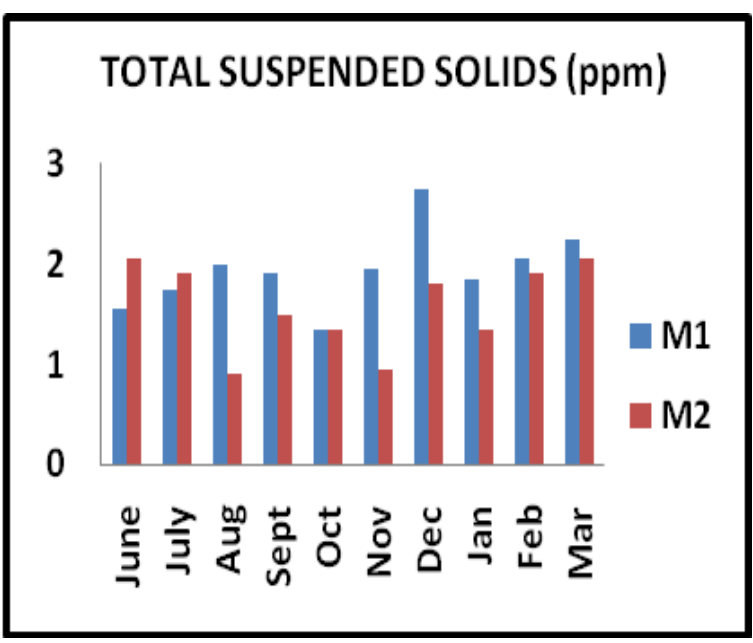

Fig.13 Monthly variation of total suspended solid in Krishnapatnam coastal mangroves

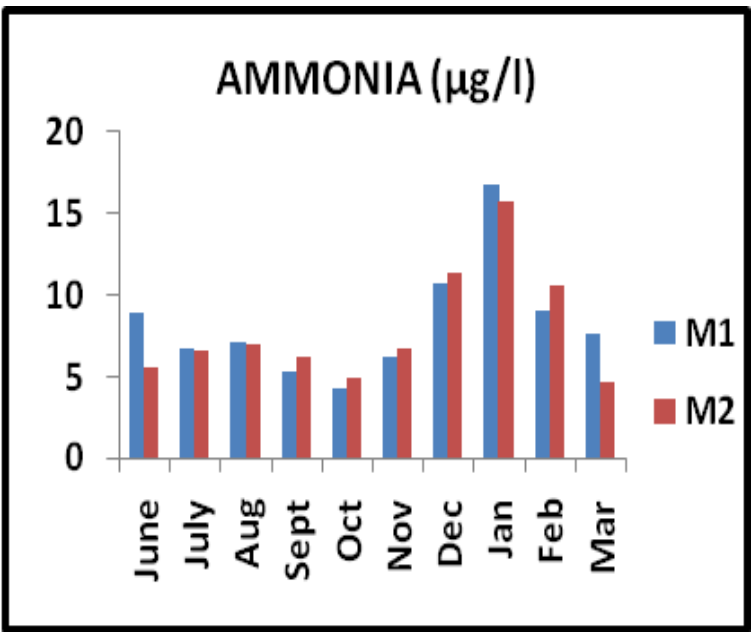

Fig.14 Monthly variation of ammonia in Krishnapatnam coastal mangroves

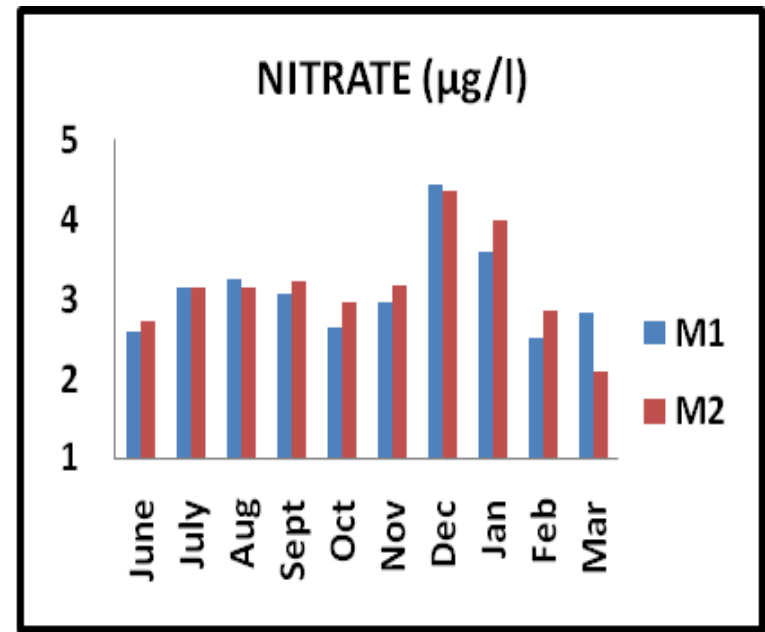

Fig.15 Monthly variation of nitrate in Krishnapatnam coastal mangroves 


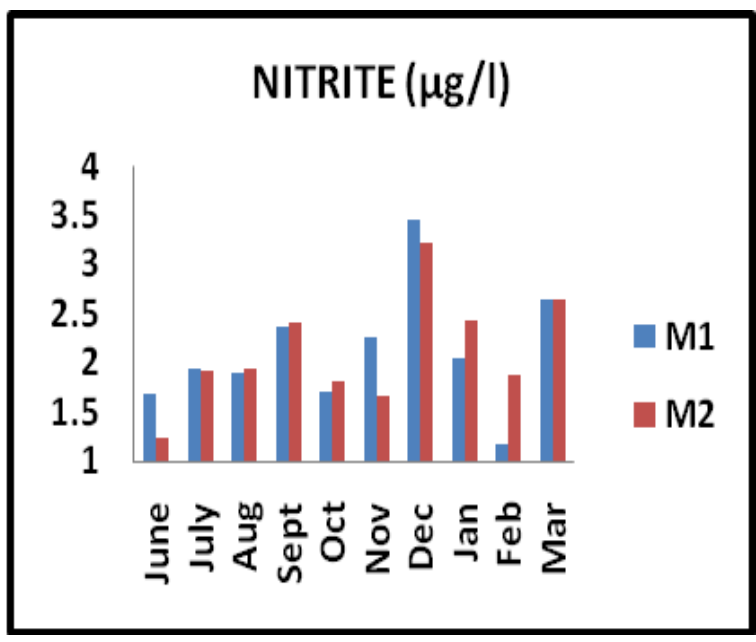

Fig.16 Monthly variation of nitrite in Krishnapatnam coastal mangroves

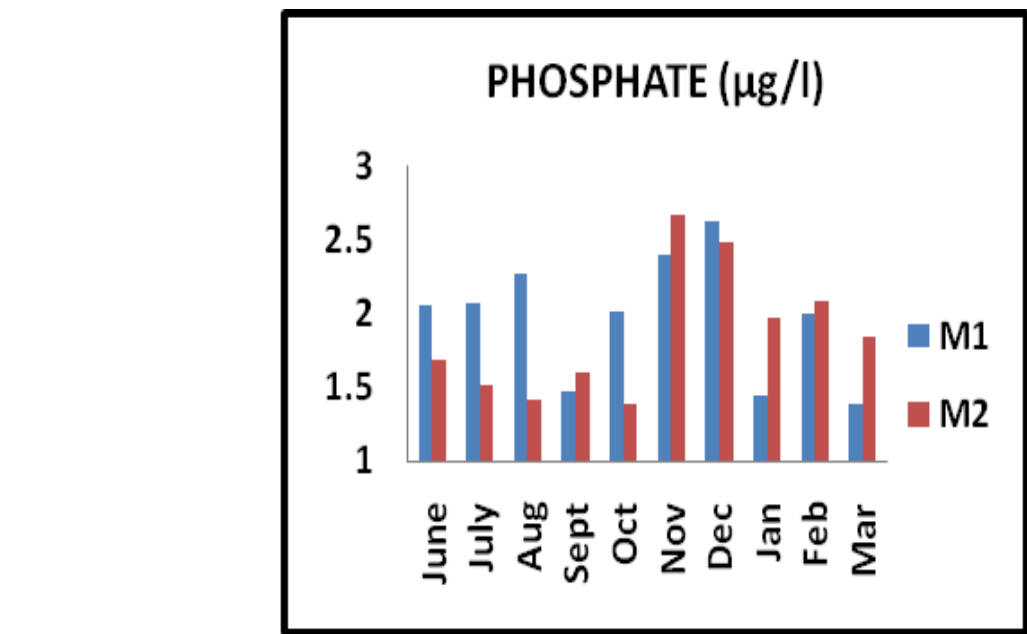

Fig.17 Monthly variation of phosphate in Krishnapatnam coastal mangroves

pH

The $\mathrm{pH}$ values were varied from 7.4 to 8.1 , high $\mathrm{pH}$ recorded during the summer season, greater photosynthetic activity whereas, the low $\mathrm{pH}$ values observed during monsoon and post-monsoon seasons might be due to decomposition of organic matter, which on biological oxidation gives up 'carbon dioxide' (Upadhyay, 1988; Rajasegar 2003 and Saravanakumar et al, 2008). Ramanathan et al., (1999) found $\mathrm{pH}$ in the range of 7.71 7.82 while working on Pichavaram mangroves. Prabhu et al., (2008) reported $\mathrm{pH}$ in the range of $7.2-8.2$ in case of Pichavaram mangroves (Fig. 5).

\section{Salinity}

Salinity is the important prime factor which determines the composition of the biological component in the mangrove environment for distributions of living organisms. The fluctuations in salinity affect the biological characteristics of the environment. The observed salinity values ranged from $21 \mathrm{ppt}$ to 33 ppt, higher values during summer could be attributed to the higher rate of evaporation. 
During the monsoon season, the rainfall and the freshwater inflow from the land in turn, might have moderately reduced the salinity. Ramamurthy et al., (2012) observed salinity ranging from 28 to $23 \mathrm{ppt}$ while working on Vedaranyam mangrove ecosystem. Srilatha $e t$ al., (2013) reported salinity ranging from 24.0 to $34.0 \mathrm{ppt}$ along Point Calimere and Muthupettai mangroves (Fig. 6).

\section{Electrical Conductivity (EC)}

Electric conductivity (EC) is an indication of the amount of salt dissolved in water. It is also defined as the number of ions (positive and negative) in water, and the water's ability to pass an electrical current. It is a useful indicator of the salinity, total salt content of a water sample. The electric conductivity (EC) varies from $32.81 \mathrm{mS} / \mathrm{cm}$ to $51.56 \mathrm{mS} / \mathrm{cm}$, higher and lower conductivity values were observed during the summer season and Monsoon transition period may possibly due to the decrease of freshwater flow and high evaporation rate vice versa. Our findings are in accordance with the reports of Kathiresan (2000) on Pichavaram mangroves, Kumara and Kumar (2011) on Kundapur mangroves, Vilas and Ashwinova (2015) on Sunderbans (Fig. 7).

\section{Dissolved Oxygen (DO)}

Dissolved oxygen is an important characteristic of water and its concentration in water is an indicator of prevailing water quality, trophic status and the ability of water to support a well-balanced aquatic life. It is essential for the respiratory metabolism of the entire aerobic aquatic life in the mangrove ecosystem. Dissolved oxygen content varied between $2.7 \mathrm{mg} / \mathrm{L}$ to $5 \mathrm{mg} / \mathrm{L}$, during the study period higher values during the monsoon season might be due to the cumulative effect of wind-generated turbulence, resultant mixing coupled with 'rainfall andriver run- off' that might have triggered comparatively low saline conditions, which might have increased the solubility of oxygen in the water and the other is true as expected for low values of D.O during summer, whose high temperatures and higher salinities might have decreased its solubility. Prabu et al., (2008) observed DO ranging from 2.4 to $5.0 \mathrm{mg} / \mathrm{L}$ in case of Pichavaram mangroves. Srilatha et al., (2013) reported DO from 3.92 to $5.22 \mathrm{mg} / \mathrm{L}$ and 3.97 to $5.33 \mathrm{mg} / \mathrm{L}$ at Point Calimere, and Muthupettai mangroves respectively. Srinivasan et al., (2013) reported DO in the range of 5.5 to $6.4 \mathrm{mg} / \mathrm{L}$ while working on Vedaranyam mangroves (Fig. 8).

\section{Biochemical Oxygen Demand (BOD)}

BOD is the measure of the extent of organic pollution in the water body; its value provides information regarding the quality of water and helps in deciding the suitability of water for different purposes. BOD values vary from $1.14 \mathrm{mg} / \mathrm{L}$ to $3.68 \mathrm{mg} / \mathrm{L}$, higher BOD values were observed during monsoon/post-monsoon seasons due to microbial demand for oxygen in the decomposition of suspended organic matter (Murugan and Ayyakkannu, 1991) accumulated mangrove leaf litter. The decaying organic matter abundant in the mangroves which increase the organic load resulting in very high BOD and lower values observed during the summer season. Kumara and Kumar (2011) reported BOD values in the range of 0.1 to $6.51 \mathrm{mg} / \mathrm{L}$ while working on Kundapura mangroves. Kavitha (2012) noticed BOD values ranging from 1.0 to 2.7 $\mathrm{mg} / \mathrm{L}$ in selected fishing grounds of Gulf of Mannar (Fig. 9).

\section{Total alkalinity}

The alkalinity of the water sample was in the range of $112 \mathrm{mg} / \mathrm{L}$ to $168 \mathrm{mg} / \mathrm{L}$, Maximum alkalinity values were observed during summer followed by other non-monsoon 
months, and minimum values during N-E monsoon, which is prevalent in the study area. The higher total alkalinity values recorded in summer irrespective of the season may have been influenced by the presence of domestic waste and the absence of normal tidal action, which would have had flushing and diluting effect on dissolved constituents as well as bicarbonates, which could increase alkalinity levels. Islam et al., (2004) reported alkalinity in the range of $74-180 \mathrm{mg} / \mathrm{L}$ along the shrimp farms of the Sundarban mangrove forest. Raj et al., (2013) noticed the average total alkalinity of $81 \mathrm{mg} / \mathrm{L}$ along the coastal zone of Muttukadu (Fig. 10).

\section{Total hardness}

Hardness is imparted to the due to the presence of divalent cations, especially that of calcium $(\mathrm{Ca})$ and magnesium $(\mathrm{Mg})$, of which in seawater magnesium is dominant and responsible for higher values of hardness observed for sea water. Total hardness values varied from to $3349 \mathrm{mg} / \mathrm{L} 5463 \mathrm{mg} / \mathrm{L}$, The observed higher summer values might be due to neritic water (which is rich in divalent cations, especially of ' $\mathrm{Mg}$ ') dominance during this season. Low values during monsoon/monsoon transition periods might be due to dilution with river water during monsoon season, though the river water is rich in ' $\mathrm{Ca}$ ', the amount of hardness it is imparted to coastal water during monsoon is less compared to the amount of hardness ' $\mathrm{Mg}$ ' is imparting during the summer season. Vilas and Ashwinova (2015) reported total hardness ranging from 1800 to $9200 \mathrm{mg} / \mathrm{L}$ in case of Sunderban Mangrove ecosystem. Mariappan et al., (2016) observed total hardness ranging from 680 to $6800 \mathrm{mg} / \mathrm{L}$ along the Pichavaram mangrove forest (Fig. 11).

\section{Total Solids (TS)}

Total solids of a water sample represent both dissolved and particulate organic matter, dissolved inorganic substances (excepting dissolved gases) and suspended inorganic substances. The sum of total suspended solids and total dissolved solids represents total solids. During the study period, on average total solids exhibited higher concentrations in summer, compared to monsoon and postmonsoon seasons. The higher levels of total solids observed during the summer season might be due to higher concentrations of TDS during this season, as they were the major contributors to the total solid content of mangrove environments (Fig. 12).

\section{Total Suspended Solids (TSS)}

The study period TSS content varied from 0.7 $\mathrm{g} / \mathrm{L}$ to $3 \mathrm{~g} / \mathrm{L}$, a high concentration of total suspended solids increases turbidity, thereby restricts light penetration and hinders photosynthetic activity. The observed higher TSS values during monsoon and immediate post-monsoon seasons compared to summer season could be attributed to the rainfall and associated turbulent conditions and to certain extent entry of dislocated fine earth materials from the catchment area through runoff, finding their way into the mangrove environment. Islam et al., (2004) observed Total Suspended Solids (TSS) varying between 0.24 and $1.22 \mathrm{~g} / \mathrm{L}$ along the shrimp farms of the Sundarbans mangrove forest. Anand and Kumarasamy (2013) observed Total Suspended Solids (TSS) varying between 0.38 and $1.48 \mathrm{~g} / \mathrm{L}$ at Kottakudi Mangrove Estuary. Rahman et al., (2016) observed Total Suspended Solids (TSS) as $0.39 \pm 0.03 \mathrm{~g} / \mathrm{L}$ along the Coastal water around the Tioman Island (Fig. 13).

\section{Total ammonia}

Ammonia is the nitrogenous end product of the bacterial decomposition of organic matter. Total ammonia in water includes both ionized (NH4+) and un-ionized (NH3) forms. The concentration of ammonia in the study area 
ranged from $3.9 \mu \mathrm{g} / \mathrm{L}$ to $19.8 \mu \mathrm{g} / \mathrm{L}$, higher concentrations of ammonia observed during post-monsoon season could partially be due to the decomposition of organic debris, land runoff water from rives to the mangroves during the monsoon season. Srilatha et al., (2013) observed the concentration of ammonia which fluctuated from 0.698 to $0.120 \mu \mathrm{mol} / \mathrm{L}$ and 0.030 to $0.744 \mu \mathrm{mol} / \mathrm{L}$ in case of Point Calimere and Muthupettai mangrove regions respectively (Fig. 15).

\section{Nitrites}

Nitrite is considered to be a very unstable component as its concentration is going to get influenced by the oxidation or reduced conditions of the system. Being an intermediate oxidation form between ammonia and nitrate can appear as a transient species either by the oxidation of ammonia or by the reduction of nitrate. The concentration of nitrites in the study area ranged between $1.01 \mu \mathrm{g} / \mathrm{L}$ to $3.52 \mu \mathrm{g} / \mathrm{L}$. Maximal values were observed during monsoon (N-E), whereas minimal values were noticed during nonmonsoon periods. Spatially not much variation was observed. The observed maximal values during monsoon season might be due to influx organic load containing nitrogenous substances, which upon being subjected to decomposition might have resulted in the formation of nitrite, the intermediate form of inorganic nitrogen in the nitrification cycle. Saravanakumar et al., (2008) noticed nitrite values ranging from 0.04 to $0.87 \mu \mathrm{M}$ along the western mangroves of Kachchh-Gujarat. Manju et al., (2012) observed the nitrite concentration ranging from 0.15 to $0.99 \mu \mathrm{M}$ at mangrove ecosystems of Kerala Coast. Srilatha et al., (2013) observed nitrite concentration ranging from 0.082 to $1.957 \mu \mathrm{mol} / \mathrm{L}$ and 0.060 to $2.082 \mu \mathrm{mol} / \mathrm{L}$ at Point Calimere and Muthupettai mangroves respectively along the southeast coast of India (Fig. 16).

\section{Nitrates}

Generally, nitrate is considered as limiting nutrient for primary production in case of seawater. The study area observed the nitrate content varied from $1.84 \mu \mathrm{g} / \mathrm{L}$ to $4.85 \mu \mathrm{g} / \mathrm{L}$, highest values recorded during monsoon and immediate post-monsoon seasons, due to the influx of river and land runoff and decomposition of mangrove leaf litterfall in the adjacent mangrove environments by the seasonal influence. Srinivasan et al., (2013) observed nitrate levels ranging from 0.17 to 6 $\mu \mathrm{mol} / \mathrm{L}$ in the coastal waters of the Bay of Bengal and Palk Strait. Kalaiarasi et al., (2012) found the nitrate values from 2.125 to $5.820 \mu \mathrm{g} / \mathrm{L}$ in S. P. Pattinam and 1.473 to $4.010 \mu \mathrm{g} / \mathrm{L}$ in Manamelkudi of Palk-Strait (Fig. 17).

\section{Phosphates}

Phosphate concentrations ranged from 1.021 $\mu \mathrm{g} / \mathrm{L}$ to $3.65 \mu \mathrm{g} / \mathrm{L}$, higher values were noticed during monsoon (N-E) and comparatively lower values during the summer season. The observed high values during monsoon season could be attributed to the runoff from agricultural and aquaculture fields (phosphatic fertilizers being the source), household activities (detergents being the source for alkyl phosphates), besides weathering of rocks (soluble alkali metal phosphates being the source) during this season. Moreover, it might also be due to the release of phosphate from the bottom mud in to the water column by turbulence and mixing during this season. The lower summer values can be ascribed to the utilization of phosphates by phytoplankton during intense photosynthetic activity characteristic of this season. Srilatha et al., (2013) found the phosphate values ranging from 0.470 to 2.620 $\mu \mathrm{mol} / \mathrm{L}$ while working on Point Calimere and Muthupettai mangroves. Ramamurthy et al., (2009). 
In Table 1 (Correlation Matrix) it depicted the bivariate inter-correlation among all water quality parameters that were observed during the study. From the table it can be observed that in case of M1 site there exists a significant (at $1 \%$ level) high positive correlation amid Air Temperature, Water Temperature; Significant (at $1 \%$ level) moderate positive correlation between Air Temperature, Salinity; $\mathrm{pH}$, Total Alkalinity; DO, BOD; Total Solids, Total Suspended Solids; Significant (at 1\% level) low positive correlation between Salinity, Total Solids; Significant (at 5\% level) low positive correlation between Air Temperature, EC; Water Temperature, Salinity; pH, Total Hardness; pH, Total Solids; Salinity, Total Alkalinity; Total Alkalinity, Total Hardness; Ammonia, Nitrate; Ammonia, Nitrite; Significant (at $1 \%$ level) high negative correlation amongst Total Alkalinity, Phosphate; Significant (at 1\% level) moderate negative correlation between Air Temperature, Nitrate; $\mathrm{pH}$, Phosphate; Salinity, DO; Salinity, Nitrate; and finally there exists a Significant (at 5\% level) low negative correlation between Air Temperature, DO; Water Temperature, DO; EC, DO; Salinity, Phosphate; TS, Phosphate.

In Table 2 (Correlation Matrix) it depicted the bivariate inter-correlation among all water quality parameters that were observed during the study. From the table 2, it can be observed that in case of $\mathrm{M} 2$ site there exists a significant (at $1 \%$ level) high positive correlation amid Air Temperature, Water Temperature; Total Alkalinity, Total Solids; Significant (at $1 \%$ level) moderate positive correlation between $\mathrm{pH}$, Total Alkalinity; $\mathrm{pH}$, total Solids; Total Hardness, Total Solids; Ammonia, Nitrate; Significant (at 5\% level) low positive correlation between Water Temperature, Salinity; Salinity, pH; Salinity, Total Alkalinity; Salinity, Total Solids; DO, BOD; Significant (at $1 \%$ level) moderate negative correlation between $\mathrm{pH}$, Nitrate; Significant (at $1 \%$ level) low negative correlation between Air Temperature, Nitrate; Water Temperature, Ammonia; Water Temperature, Nitrate; finally there exists a Significant (at 5\% level) low negative correlation between Air Temperature, Ammonia; Water Temperature, DO; Salinity, DO; Salinity, BOD.

The Dendrograms shows the cluster being combined and the values of the coefficient at each step. Results clearly show that two stations could be distinguished that apparently reflected differences in water parameters within Krishnapatnam mangroves.

In conclusion, this study will provide baseline information on these parameters of Mangrove region in the Krishnapatnam coastal region (Southeast coast of India) which would be helpful in assessing the changes in water quality that might happen in long run due to port development, regular port activities, industries that are in operation in and around the port area, shrimp farming etc.

\section{Acknowledgment}

The authors gratefully acknowledge the facilities and the support provided by the Dean and HOD of Department of Aquatic Environment management, of the College of Fishery Science, Sri Venkateswara Veterinary University, Tirupati.

\section{References}

Anand and Kumarasamy. P. (2013). Studies on the physico-chemical status of Kottakudi mangrove estuary, Thiruppullani, Ramanathapuram district, Tamil Nadu. Advances in Applied Science Research, 4(6), 173177.

APHA. (2005). Standard Methods for Examination of Water and 
Wastewater", (American Public Health Association WWA), Washington, D.C.

Badarudeen, A., Damodaran, K. T., Sajan, K., and Padmalal, D. (1996).Texture and geochemistry of the sediments of a tropical mangrove ecosystem, southwest coast of India. Environmental Geology, 27(3), 164169.

Behera, B.C., Mishra, R.R., Patra, J.K., Dutta, S.K., and Thatoi, H.N. (2008). Physico Chemical Properties of Water Sample Collected From Mangrove Ecosystem of Mahanadi River Delta, Odisha, India, American Journal of Marine Science, 2(1), 19-24.

Islam, M.L., Alam, M.J., Rheman, S., Ahmed, S.U. and Mazid, M.A. (2004). Water quality, nutrient dynamics and sediment profile in shrimp farms of the Sundarbans mangrove forest, Bangladesh. Council of Scientific and Industrial Research, 33(2), 170-176.

Kathiresan K (2000). A review of studies on Pichavaram mangrove, Southeast India. Hydrobiologia, 430, 185-205.

Kavitha, M., (2012). Hydrobiological parameters of selected fishing grounds of Gulf of Mannar. M.F.Sc., Thesis, Tamilnadu Veterinary and Animal Sciences University, Chennai, India.

Kumar and Vijaya Kumara. (2011). Avifaunal diversity of mangrove ecosystem, Kundapura, Udupi district, Karnataka, India. Recent Research in Science and Technology, 3.No.10.

Mariappan., Nivas, A., Kanmani, T. and Parthiban, S. (2016). A study of water quality status of mangrove vegetation in Pichavaram estuary. Journal of Agriculture and Ecology Research International, 5(3),1-11.

Mastallar, M.C (1996). Destruction of mangrove wetlands causes and consequences. Natural Res Dev 43/44:37-57.

Mohammad M., Rahman, Mir T. Rahman1, Mohammad S. Rahaman, Farzana Rahman, Jasim U. Ahmad, Begum Shakera, and Mohammad A. Halim. (2013). Water Quality of the World's Largest Mangrove Forest. Borderless Science Publishing, 1(2), 141-156.

Murugan, A. and K. Ayyakkannu (1991).Ecology of Uppanar backwater, Cuddalore. I. Physicochemical parameters. Mahasagar. Bulletin of National Institute Of Oceanography. 24: 31-38.

Orathai Jitthaisong, Pricha Dhanmanonda, Kasem Chunkao and Sakhan Teejuntuk (2012). Water quality from mangrove forest: the king's royally initiated laem phak bia environmental research and development project, phetchaburi province, Thailand. Modern Applied Science, 6(8),1-8.

Prabhu, V.A., Rajkumar, M. and Perumal, P. (2008). Seasonal variations in physico-chemical characteristics of Pichavaram mangroves, Southeast coast of India. Journal Environmental biology, 29(6), 945-950.

Raj, V.M., Sivakumar, S., and Padma, S. (2013 b). Comparative study on the water quality parameters of Muttukadu estuary and near coastal zone of Muttukadu, Tamilnadu, India.

International Journal of Environmental Biology, 3(4), 147-150.

Rajasegar, M., 2003.Physico-chemical characteristics of the Vellar estuary in relation to shrimp farming. Journal of Environmental Biology, 24, 95-101.

Ramamurthy, K., Radhika, A., Kavitha, Amirthanayagi and Raveendran, S. (2012). physico-chemical analysis of soil and water of Vedaranyam mangrove forest, Tamil Nadu, India. 
International Journal of Advanced Life Sciences, 3(1), 65-71.

Ramanathan, A.L., Subramanian, V., Ramesh, R., Chidambaram, S. and James, A. (1999) Environmental geochemistry of the Pichavaram mangrove ecosystem (tropical), south-east coast of India. Environmental Geology, 37(3), 223233.

Saravanakumar, A., Rajkumar, M., Sesh Serebiah, J. and Thivakaran, G.A. (2008). Seasonal variations in physico-chemical characteristics of water, sediment and soil texture in arid zone mangroves of Kachchh-Gujarat. Journal of Environmental Biology, 29(5) 725-732.

Srilatha, G., Varadarajan, D., Chamundeswari, K. and Mayavu, P. (2013). Study on physicochemical parameters in different mangrove regions, Southeast Coast of India. Journal of Environmental And analytical Toxicology, 3(5), 2-8.

Srinivasan, V., Natesan, U., and Parthasarathy, A. (2013). Seasonal variability of coastal water quality in bay of Bengal and Palk strait, Tamilnadu, southeast coast of India. Brazilian Archives of Biology and Technology, 56 (5), 875884.

Strickland, J.D.H. and Parsons, T.R (1972).A practical hand book of sea water analysis. Fisheries Research Board of Canada, Bulletin No. (167), 311.
Subramanian, B., and Mahadevan, A. (1999). Seasonal and diurnal variations of hydrobiological characters of coastal waters of Chennai (Madras) Bay of Bengal. Indian Journal of Maine Sciences, 28, 429-433.

Upadhyay, S. (1988). Physico-chemical characteristics of the Mahanadhi estuarine ecosystem, east coast of India. Indian journal of marine sciences, 17, 19- 23.

Venkataraman, K., andWafar, M. (2005).Coastal and marine biodiversity of India. Journal of Marine Sciences, 34(1), 57-75.

Vilas Mane Ashish. and Ashwinova, G. (2015). Water and soil quality analysis of selected areas of Sunderban and mapping using GIS technique. International Journal of Research In Chemistry And Environment, 5(4), 4459.

Wahid Shahriar, M.D., Mukand Babel, S. and Abdur, Rahmanbhuiyan. (2007). Hydrologic monitoring and analysis in the Sundarbans mangrove ecosystem, Bangladesh. Journal of Hydrology, 332(3-4), 381-395.

Zafar Adeel and Robert Pomeroy (2002). Assessment and management of mangrove ecosystems in developing countries. Trees-Structure and Function, 16(2), 235-238.

\section{How to cite this article:}

Sri Dattatreya, P., K. Madhavi, B. Satyanarayana, Adnan Amin and Harini, C. 2018. Assessment of Physico-chemical Characteristics of Mangrove Region in the Krishnapatnam Coast, India. Int.J.Curr.Microbiol.App.Sci. 7(05): 2326-2342. doi: https://doi.org/10.20546/ijcmas.2018.705.268 